\title{
Evidences of Factorial Structure and Precision of Phonemic Awareness Tasks (TCFe) ${ }^{1}$
}

\author{
Dalva Maria Alves Godoy ${ }^{2}$ \\ Universidade do Estado de Santa Catarina, \\ Florianópolis-SC, Brazil
}

\author{
Hugo Cogo-Moreira \\ Universidade Federal de São Paulo, \\ São Paulo-SP, Brazil
}

\begin{abstract}
To assess phonological awareness - a decisive skill for learning to read and write - it is necessary to provide evidence about an instrument construct to present trustworthy parameters for both empirical research and the development of educational intervention and rehabilitation programs. In Brazil, at this moment, there are no studies regarding the internal structure for tests of phonological awareness. This article shows the factorial validity of a test of phonological awareness composed by three subtests: two tasks of subtraction of initial phoneme and one of phonemic segmentation. The multidimensional confirmatory factorial analysis was applied to a sample of 176 Brazilian students $\left(M_{\text {age }}=9.3\right.$ years $)$ from the first to fifth grade of elementary school. Results indicated a well-adjusted model, with items of intermediate difficulty and high factor loadings; thus, this corroborated the internal structure and well-designed theoretical conception.
\end{abstract}

Keywords: phonological awareness, test validity, literacy

\section{Evidências da Estrutura Fatorial e Precisão de Tarefas de Consciência Fonêmica (TCFe)}

\begin{abstract}
Resumo: Para avaliar a consciência fonológica, habilidade determinante para a aprendizagem da leitura e da escrita, é necessário prover evidências acerca do construto que um dado instrumento se propõe a mensurar de modo a fornecer parâmetros confiáveis tanto para a pesquisa empírica como para o desenvolvimento de programas de intervenção educacional e de reabilitação. No Brasil, até o momento, não há estudos de evidências de validade com base na estrutura interna para testes de consciência fonológica. Este artigo apresenta os resultados para a validade de um teste de consciência fonológica constituído por três sub-testes: duas tarefas de subtração do fonema inicial e uma de segmentação fonêmica. A análise fatorial confirmatória multidimensional foi aplicada a uma amostra de 176 estudantes brasileiros $\left(M_{\mathrm{IDADE}}=9,3\right.$ anos $)$ de $1^{\circ}$ ao $5^{\circ}$ ano do ensino fundamental. Resultados indicaram modelo bem ajustado, com itens de dificuldade mediana e cargas fatoriais altas; corroborando a estrutura interna e concepção teórica adequadas.
\end{abstract}

Palavras-chave: consciência fonológica, validade do teste, alfabetização

\section{Evidencias de la Estructura Factorial y Precisión de las Pruebas de Conciencia Fonémica (TCFe)}

\begin{abstract}
Resumen: Para evaluar la conciencia fonológica, habilidad determinante para el aprendizaje de la lectura y escritura, es necesario proporcionar evidencias a cerca del constructo que un dicho instrumento se propone a medir a fin de tener parámetros fiables para la investigación empírica y para el desarrollo de programas de intervención educativa y de rehabilitación. En Brasil, hasta el momento, no hay estudios de evidencia de la validez basada en la estructura interna para pruebas de conciencia fonológica. Este artículo presenta los resultados para la validez de una prueba de conciencia fonológica constituida por tres sub-pruebas: dos de subtración del fonema inicial y una de segmentación fonémica. El análisis factorial confirmatorio multidimensional fue aplicado a una muestra de 176 estudiantes brasileños $\left(M_{\text {edad }}=9,3\right.$ años) de $1^{\circ}$ a $5^{\circ}$ año del enseñanza básica. Los resultados indicarán un modelo bien ajustado, con items de dificuldad mediana y cargas factoriales altas; corroborando la estructura interna y la concepción teórica adecuadas.
\end{abstract}

Palabras clave: conciencia fonológica, validación de test, alfabetización

One of the most relevant findings in the field of reading in the last four decades has indicated phonological awareness

\footnotetext{
${ }^{1}$ Support: This research received financing from Fundação de Amparo à Pesquisa e Inovação do Estado de Santa Catarina (FAPESC - T.O. $\mathrm{n}^{\circ}$ 2013 TR 3437). Postdoctoral scholarship granted by Coordination for the Improvement of Higher Education Personnel (CAPES - Protocol no. 10770/13-5).

${ }^{2}$ Correspondence address:

Dalva Maria Alves Godoy. Centro de Ciências Humanas e da Educação. Universidade do Estado de Santa Catarina. Av. Madre Benvenuta, 2007, Campus Itacorubi. CEP 88035-001. Florianópolis-SC, Brazil. E-mail: dalvagodoy@gmail.com
}

as the strongest predictor of success for learning an alphabetic writing system (Castles \& Coltheart, 2004; Melby-Lervag, Lyster, \& Hulme, 2012; Wimmer, Landerl, Linortner, \& Hummer, 1991). The predictive strength in phonological skills for determining reading skills was extensively corroborated through different alphabetic orthographies, both transparent and opaque. It is known that in transparent orthographies, phonological awareness, especially the phonemic level, exerts a strong influence from the beginning of the acquisition process. Such is the case, for instance, of Italian (Cossu, Shankweiler, Liberman, Katz, \& Tola, 1988), Spanish (Defior, 
Serrano, \& Marín-Cano, 2008), Brazilian Portuguese (Godoy \& Pinheiro, 2013), Greek (Rothou, Padeliadu, \& Sideridis, 2013), and Germanic orthographies (Wimmer et al., 1991), whereas in more opaque orthographies, such as English, the influence lingers for a longer period (Moll et al., 2014).

The contribution of phonological awareness for learning to write has also been observed (Caravolas, 2004; Defior \& Serrano, 2011a). In a recent study that indicates contrasts in the varying degrees of orthographic consistency in five European languages (English, French, German, Hungarian, and Finnish), phonological awareness was observed to be the factor that best explains the variance in writing in all of the orthographies (Moll et al., 2014).

It has been verified that the lack of phonological awareness, at the phonemic level, is the primary cause of developmental dyslexia in alphabetic orthographies (Defior \& Serrano, 2011a; Hulme \& Snowling, 2014), whereas phonological awareness, along with the knowledge of grapheme-phoneme correspondence, is considered the most solid pillar for alphabetic teaching (Ehri et al., 2001). Hence, phonological awareness training has been recommended as an important educational and therapeutic resource (Carson, Gillon, \& Boustead, 2013).

Despite the validity of these results, questions still persist so as to understand when and how the phonological awareness skills exercise their influence on the basic processes of learning written language, and how these skills develop in contact with this learning in different orthographies - that is, in what manner the characteristics of each orthography and phonology of a language influence this development (Caravolas et al., 2012; Caravolas, Lervag, Defior, Málková, \& Hulme, 2013; Duncan et al., 2013).

Phonological awareness, the ability to reflect on the constituents of speech sounds, is observed by the participant's conscious and intentional distinction of syllabic, intrasyllabic and phonemic units. This is manifested through the performance of tasks involving the identification and manipulation of parts of a word in terms of rhyming, syllable, and phoneme, which makes it highly complex. This construct, led by metacognitive activity, involves directing attention to, retaining the memory of, and producing answers based on operations of identification of similarity, analysis and/or synthesis, substitution, addition and reversion of sound units. Some of these skills, as is the case of operations with regard to syllables and rhymes, develop in the course of linguistic experience. However, only when one learns an alphabetic writing system can we observe the emergence of phonemic awareness, the highest level of phonological awareness, which, in turn, is an essential skill for learning to read in an alphabetic writing system (Defior \& Serrano, 2011b; ScliarCabral, 2002).

The assessment of phonological awareness skills is fundamental for planning school activities that aid children (and adults) in learning to read and write. Such assessments further aids in the development of educational programs in that area; for helping the early identification of children who are under a risk of developing difficulties in learning; for guiding the interventions along the rehabilitation process and, lastly, for supporting the expansion of national and international research on the topic.

The phonological awareness tasks demands the employment of different cognitive skills (for instance, skills that involve analysis, synthesis or analysis-synthesis). Furthermore, due to its requirement of reflecting on the speech chain, it gathers factors that suggest ease or difficulty, depending on the syllabic structure that composes it. Although phonological awareness is conceived in three different levels - rhyme, syllable and phonemes -, it is known that, depending on the degree of what the task demands, the child may completely fail at the performance of one task while succeeding at another. For example, tasks involving identifying similarities in relation to initial or final phonemes in a set of words, which are known as oddity tasks (Bradley \& Bryant, 1983), may be easily accomplished by preschoolers, but they will hardly succeed at performing a task involving the segmentation of a word into phonemes, a metalinguistic task. This is one of the challenges in the assessment of phonological awareness, since it draws a distinction between implicit and explicit skills (Gombert, 2003).

In Brazil, according to an investigation of theses and dissertations that used phonological awareness tests between 2000 and 2010, it was observed that many researchers either elaborated their own tests or tasks exclusively conducted for that occasion, or adapted tests by other authors (Godoy, Fortunato, \& Paiano, 2014). During this period, two assessment instruments, elaborated by Brazilian researchers, were among the most used. These were Phonological Awareness Test by Oral Production (Prova de Consciência Fonológica por Produção Oral [PCFO], in Portuguese, A. G. S. Capovilla \& F. C. Capovilla, 1998, 2000), and Confias (Moojen et al., 2003). Recently, results have been published on the construct validity based on the internal structure of the Phonological Awareness Test by Oral Production (PCFO) concerning observable measures; that is, considering the total or standard composite scores (Dias, Duarte, Macedo, \& Seabra, 2012). However, neither one of these instruments present factorial validity results in which the construct is assessed in a structural manner, through factor analysis or latent variable modelling, with the construct here being considered a "synonym of a latent variable and not directly observable" (Urbina, 2014, p. 170).

Phonological awareness, a latent trait, is an underlying factor in a set of tasks designated to measure this phenomenon, such as, for instance, segment addition tasks, alliteration, segmentation, etc. In the confirmatory factor analysis, what is assessed is the impact of this latent trait on these items or tasks that were supposedly created to assess it. Phonological awareness, per se, is independent from the items, and the performance in each item is impacted by this latent phenomenon. Thus, a causality route (from cause to effect) that goes from the latent phenomenon (cause) to success or failure in a given task is acknowledged.

The confirmatory factor analysis allows testing theories regarding relations between latent factors, which are measures not directly observable, and their manifest indicators (for instance, success or failure in items that constitute a task), 
as one of the three ways of providing evidence concerning construct validity, as indicated by authors (Raykov \& Marcoulides, 2011). The relation between manifest indicators (items) and latent factors is particularly relevant when using this analytical technique that, a priori, tests a theory, thus solving a serious problem of infinite solutions emerging from exploratory factor analyses (Raykov \& Marcoulides, 2011). An advantage of this kind of analysis is that it allows testing two assumptions by Cronbach's alpha, whether the model is: (a) congeneric (Green, Lissitz, \& Mulaik, 1977) and (b) tau-equivalent (Raykov, 1997, 2001). Frequently, studies that present reliability rates for phonological awareness tests report Cronbach's alpha; however, formally, these two assumptions have not been tested, which means that such estimates may be underestimated or overestimated (Raykov, 2001).

When intending to assess the factors underlying the performance of tasks or items elaborated to measure something that cannot be directly observed, such as the phonological awareness, a complex and multidimensional construct, the confirmatory factor analysis, according to Raykov \& Marcoulides (2011), can be used advantageously to solve questions concerning construct validity. This term, construct validity, discussed by the authors (analytically assessed through confirmatory/exploratory analyses) is analogous to the evidence of validity based on the internal structure, in the context of the American Educational Research Association, the American Psychological Association and the National Council on Measurement in Education (2014).

This article aims to present the first pieces of evidence resulting from the confirmatory factor analysis of a phonological awareness test on a phonemic level, constituted of three domains: two subtraction tasks and one segmentation task. These results integrate a more extensive research conducted in the scope of Universidade do Estado de Santa Catarina, which sought to investigate the contribution of rapid automatized naming, working memory, phonemic-level phonological awareness, and grapheme recognition skills for learning to write words in first to fifth grades of elementary schools. The choice to investigate phonological awareness through phonemic level tasks is only justified, a priori, by the relevance of this skill level for learning the written language. Furthermore, previous studies (Godoy, 2005) have indicated that, upon entering the first year, children deliver good performances in syllabic level tasks and, consequently, for the research in question, this sort of task would be too easy in the following years. According to these results, the phonemic segmentation task is the most important phonemic skill that enables predicting future performances in reading and writing Brazilian Portuguese by the end of the second year (Godoy, Defior, \& Pinheiro, 2007).

The three phonemic-level sub-tests, object of this analysis, henceforth named TCFe, Phonemic Awareness Tasks (Tarefas de Consciência Fonêmica, in Portuguese), were adapted and/or elaborated by Godoy $(2001,2005)$. Godoy (2001) adapted the phonological awareness tests from Batterie d'évaluation du langage écrit et de ses troubles (BELEC) developed by Mousty, Leybaert, Alegria, Content, and Morais (1994) to Brazilian Portuguese. This set of tests is composed of two syllabic level tests (with subtraction and inversion tasks), four phonemic level tests (with subtraction and inversion tasks, with different syllabic structures), and one listening acronyms test (spoonerism). For the present research, only the phonemic subtraction tasks were used, with CVC and CCV syllabic structures. The subtraction task in two different phonological structures is planned with the aim to progressively observe the participants' performances, because, a priori, it was assumed that the performance of the subtraction of the initial phoneme in the CVC structure would be easier to solve than in the CCV structure. It is important to bear in mind that in Brazilian Portuguese, the vowel is always the obligatory syllable nucleus, as it is also more perceptible, whereas the consonantal group demands better phonological representation of the segments for the accomplishment of the decomposition and subtraction task. As for the phonemic segmentation task, it was adopted from Godoy's doctorate research (2005), and had been elaborated for the research. The preference for its use has been previously mentioned.

\section{Method}

\section{Participants}

The sample comprised 176 students, distributed in the following manner: first grade $(n=31)$, second grade $(n=40)$, third grade $(n=26)$, fourth grade $(n=39)$ and fifth grade $(n=$ $40)$. The average age is 9.3 years $(S D=1.54)$. All the students were enrolled at the same municipal public school.

\section{Instruments}

Phonemic Awareness Tasks (Tarefas de Consciência Fonemica - $\mathrm{TCFe}$ ). All the stimuli in all the three tasks applied are pseudowords that generate pseudowords as answers. For each task, students are presented with four training stimuli that encompass all the typical characteristics of the items in the exam. The instruction for performing the task, as well as the training stimuli, was delivered orally by the examiner, and the assessment stimuli were pre-recorded.

Segmentation. The task consists of counting and enunciating the segments of the pseudowords presented. It comprises eight items - six monosyllabic words and two disyllabic words, with the following syllabic structure: $\mathrm{CV}$ (chó, rá, fi), CVC (gus, bór, fer), and CVCV (rivó, jáfi).

Subtraction. The task consists of always mentally subtracting the first phoneme of the presented pseudoword and indicating the remainder. Two tasks are presented: (a) CVC structure - sixteen items (fér, sur, pes, rus, jar, ber, guis, zór, xos, tor, lis, mir, dós, vés, nur, kas); and (b) CCV structure ten items (prõ, fle, dre, plã, kru, blo, tru, glim, vra, kli).

\section{Procedure}

Data collection. All the stimuli were recorded in the linguistic variation pertaining to the participants' region. The participants' answers were recorded and written down on an answer sheet. The application sessions were one-onone, conducted in a room within the school space, and did 
not exceed 40 minutes. On the occasions in which the child demonstrated signs of tiredness or dispersion, the assessment was interrupted and continued on a different day. More than one assessment session was needed only exceptionally. We sought a playful interaction with the child through a pleasant and enjoyable conversation, but no orthographic clues or support through physical materials were provided for the representation of the stimuli or segments during the performance of the tasks.

Data analysis. The three phonemic awareness tasks are understood, a priori, as three domains, due to the different degrees of cognitive demand for the performance of each task. In order to assess the fit of this theoretical, multidimensional model, the confirmatory factor analysis was used through a weighted least squares estimator (weighted least squares with mean and variance, WLSMV); such estimator is a default for the Mplus software when there are categorical indicators. Four fit indexes and their respective cut-points were applied: (a) the $\chi^{2}$ (chi-square), developed by Jöreskog (1969), in which it is expected that the associated $\mathrm{p}$-value be greater than 0.05 ; (b) the Tucker-Lewis index (TLI), developed by Tucker and Lewis (1973). It compares the lack of fit in a specified model with the lack of fit in the null model $\left(\mathrm{H}_{0}\right)$. It is recommended that the TLI be greater than .90; (c) the Comparative fit index (CFI), developed by Bentler (1990). It compares the specified model with the null model, which assumes covariances at zero between the variables observed (the items), in which values greater than .95 are indicative of models with good fit; and (d) the Root Mean Square Error of Approximation (RMSEA), in which values less than .06 indicate a good fit (Hu \& Bentler, 1998).

For each domain, total information curves were obtained, which indicate how informative a given domain under assessment is, or how precise certain latent data is, throughout the entire latent spectrum of the same domain. It is expected that a test be very informative throughout the entire latent trait; however, the information from a given latent trait varies over the course of the spectrum.

\section{Ethical Considerations}

This study has been approved by the Research Ethics Committee of the Universidade do Estado de Santa Catarina (Protocol no. 185/2010) in accordance with the norms and guidelines in Resolution 196/96 by the National Health Council.

\section{Results}

Factor analysis, used for confirming the multidimensional structure initially proposed, indicated an inadmissible error, known as empty bivariate cells, in some of the pairs of items. One of the items that constitute that pair had to be removed, namely: one item in the /fi/ phonemic segmentation task, and two items in the CVC phonemic subtraction task (/lis/, $/ \mathrm{kas} /$ ). Such a problem may emerge due to asymmetry in the standard of success/fail answers in each of the tasks (for instance: $95 \%$ fail versus $5 \%$ success on one given item, $98 \%$ versus $2 \%$, and so on).

Once due exclusions were made, adequacy rates indicated a well-adjusted model: $\chi_{(430)}^{2}=469.533, p=.0145$; RMSEA $=.030$; CFI and TLI $=.995$. It can be noted that the value of $\chi^{2}$ was less than the cut-point; however, since the model is complex $(\mathrm{gl}=430)$, the p-value associated with this statistical test is being penalised by the referred complexity. In this case, it is worth indicating that it is not just an adequation index that should be considered, but the entire set. The RMSEA index, in this case, already regards the complexity of the model in its formulation.

The diagram that represents the conception for the proposed multidimensional model is shown in Figure 1, in which the squares represent the observable variables in the model, also known as manifest variables or items, and the ovals represent the latent factors. The correlation between the latent factors is of the following magnitude and statistical significance: CVC subtraction with segmentation $=.830(p<.001)$, CVC subtraction with CCV subtraction $=.791(p<.001)$, and CCV subtraction with segmentation $=.743(p<.001)$.

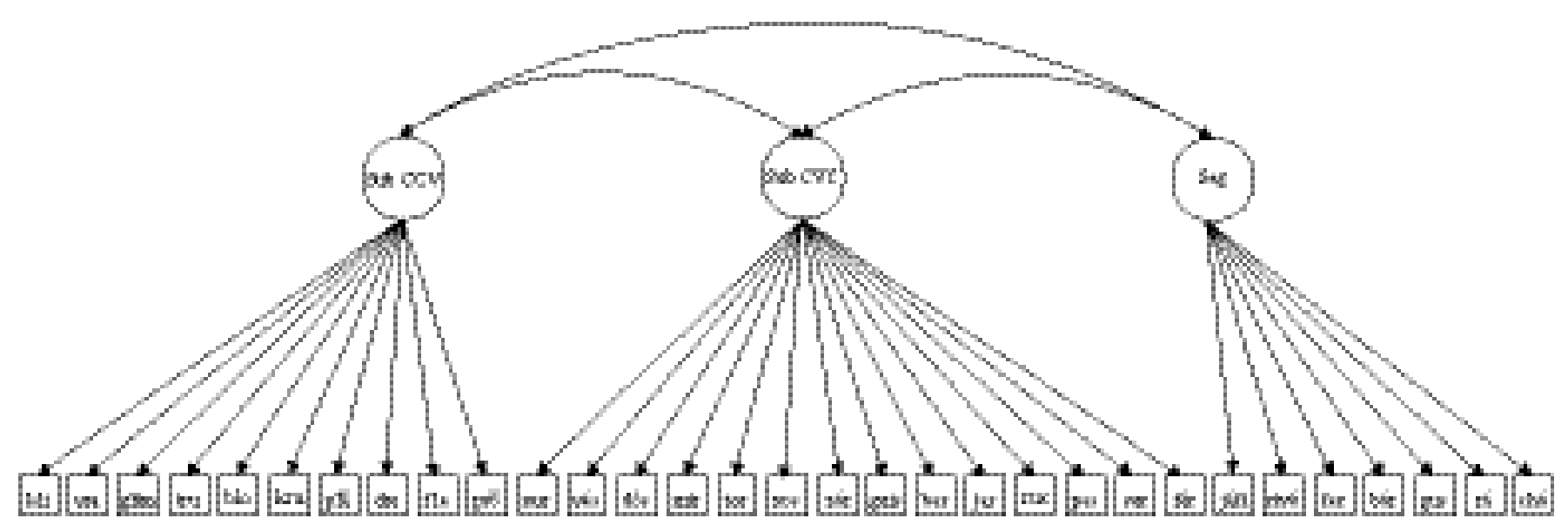

Figure 1. Multidimensional model for the TCFe. 
As can be seen in Figure 2, the curve information analysis indicates that the most informative domain is the CVC phonemic subtraction (greatest peak of information), followed by the CCV subtraction and, lastly, by the segmentation domain. The information peaks are observed around zero, indicating that the tasks are more appropriate for participants with moderate skills.

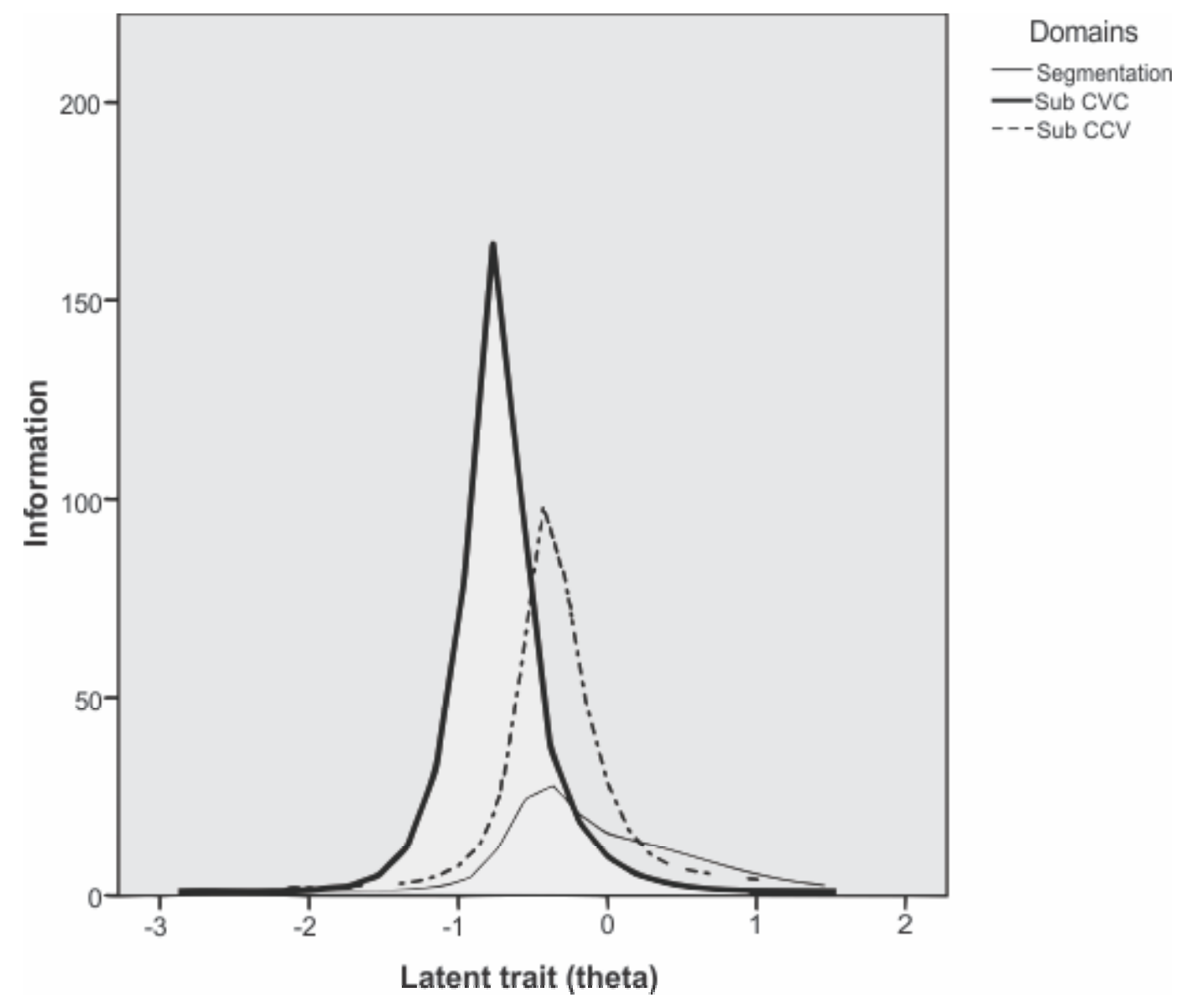

Figure 2. Information curves for each of the three domains assessed through TCFe.

Table 1 presents the standardised factor loadings $(\lambda)$ for the three latent factors. The closer to + or -1 , the more a given item is correlated to a given factor; on the other hand, the lesser the factor loading (closer to zero) is, the lesser the correlation of the item with the factor. All of the items presented high factor loadings, with an average of $\lambda=.8822$ (the lowest being the CCV subtraction domain item, [prõ], at $\lambda=.714$ ).

Table 2 presents the threshold for each one of the items assessed, indicating the amount of latent traits that a given participant should possess in order to deliver a correct answer; in other words, it is the amount of skill in a given factor that the participant should have in order to succeed in an item, instead of failing it. It can be noticed that, generally, the necessary threshold for children to succeed in an item is approximately zero, and that represents the average of the trait assessed.

\section{Discussion}

The phonemic awareness skills have been shown by international research as being essential for learning an alphabetical system. Its importance has driven the development of programs for the stimulation of these skills in the scope of education, seeking to help and ease the acquisition of reading and writing. Similarly, the stimulation of phonemic awareness appears to be an indispensable instrument for rehabilitation in cases of dyslexia.

The assessment of these skills is thus necessary to provide parameters not only for educational activity but also for therapeutic activity and for developing research in Brazil. It has been verified that, till now, there has been no evidence of factorial validity for phonemic awareness testing in national Brazilian territory, and this is the motivating rationale behind this study. In this context of confirmatory factor analysis, this study provided validity rates based on the internal structure of a model constituted of three dimensions in phonemic-level phonological awareness, namely: one phonemic subtraction task with the CVC structure, one phonemic subtraction task with the $\mathrm{CCV}$ structure and one segmentation task. 
Paidéia, 25(62), 363-372

Table 1

Standardised Factorial Loadings and Standard Error (SE) for Each Item in Each Domain

\begin{tabular}{|c|c|c|c|}
\hline Domains & Item & Factorial Loadings & SE \\
\hline \multirow[t]{7}{*}{ Segmentation } & $\mathrm{CHO}$ & .914 & .041 \\
\hline & RA & .974 & .036 \\
\hline & GUS & .793 & .047 \\
\hline & BOR & .740 & .056 \\
\hline & FER & .876 & .037 \\
\hline & RIVO & .814 & .043 \\
\hline & JAFI & .846 & .043 \\
\hline \multicolumn{4}{|c|}{ CVC Subtraction } \\
\hline & FER & .958 & .032 \\
\hline & SUR & .852 & .045 \\
\hline & PES & .924 & .033 \\
\hline & RUS & .841 & .044 \\
\hline & JAR & .909 & .034 \\
\hline & BER & .946 & .027 \\
\hline & GUIS & .928 & .032 \\
\hline & ZOR & .904 & .038 \\
\hline & XOS & .939 & .028 \\
\hline & TOR & .969 & .025 \\
\hline & MIR & .984 & .021 \\
\hline & DOS & .977 & .019 \\
\hline & VES & .993 & .016 \\
\hline & NUR & .871 & .037 \\
\hline \multicolumn{4}{|c|}{ CCV Subtraction } \\
\hline & PRÕ & .714 & .065 \\
\hline & FLE & .745 & .065 \\
\hline & DRE & .932 & .030 \\
\hline & PLÃ & .647 & .073 \\
\hline & KRU & .963 & .027 \\
\hline & BLO & .897 & .040 \\
\hline & TRU & .914 & .032 \\
\hline & GLIM & .691 & .062 \\
\hline & VRA & .983 & .028 \\
\hline & KLI & .912 & .039 \\
\hline
\end{tabular}


Godoy, D. M. A., \& Cogo-Moreira, H. (2015). Factorial Structure of Phonemic Awareness Task.

Table 2

Threshold and Standard Error (SE) for Each Item

\begin{tabular}{|c|c|c|}
\hline Item & Threshold & $\mathrm{SE}$ \\
\hline $\mathrm{CHO}$ & -.253 & .096 \\
\hline RA & -.484 & .099 \\
\hline GUS & .343 & .097 \\
\hline BOR & .239 & .096 \\
\hline FER & .036 & .095 \\
\hline RIVO & .313 & .096 \\
\hline JAFI & .283 & .096 \\
\hline FER & -.862 & .109 \\
\hline SUR & -.583 & .101 \\
\hline PES & -.725 & .104 \\
\hline RUS & -.468 & .099 \\
\hline JAR & -.652 & .102 \\
\hline BER & -.688 & .103 \\
\hline GUIS & -.706 & .104 \\
\hline ZOR & -.688 & .103 \\
\hline XOS & -.670 & .103 \\
\hline TOR & -.782 & .106 \\
\hline MIR & -.801 & .107 \\
\hline DOS & -.782 & .106 \\
\hline VES & -.744 & .105 \\
\hline NUR & -.358 & .097 \\
\hline PRÕ & .420 & .100 \\
\hline FLE & -.371 & .100 \\
\hline DRE & -.291 & .099 \\
\hline PLÃ & -.030 & .097 \\
\hline KRU & -.436 & .101 \\
\hline BLO & -.574 & .103 \\
\hline TRU & -.371 & .100 \\
\hline GLIM & -.045 & .097 \\
\hline VRA & -.591 & .104 \\
\hline KLI & -.556 & .103 \\
\hline
\end{tabular}


Considering the four adjustment indexes obtained through the factor analysis for the model, it is granted that the TCFe composes a multidimensional construct wherein the tasks are highly correlated to each other. Although good adjustment has been found for the multidimensional model, the indicators per se do not enable future research or therapies, for using the three found domains as subscales. Testing if the child's domain over segmentation is greater compared to phonemic subtraction is also not recommended, since we do not have evidence of the viability of using these domains as subscales. Multidimensionality does not guarantee that the subscales may provide significant and reliable information on subdomains that are unique and specific, from a general construct, for phonemic awareness (Reise, Bonifay, \& Haviland, 2013). For the assessment of the viability of the subscales, general-specific models, also known as bifactorial models, and indexes such as the hierarchical omega will be required (Reise, Moore, \& Haviland, 2010).

The TCFe tasks have different information functions in terms of precision. Precision informs the accuracy, or adequacy, with which the subdomains (task items) represent what they intend to represent or measure, that is, the latent trait under assessment (Pasquali, 2007). Hence, precision indicates to which levels of latent traits the set of items provides adequate information. It is observed that the TCFe's most informative domain is represented by CVC subtraction, and the least informative is the segmentation. The information peak for CVC subtraction shifts to the left, pointing to inferior skill levels that are required, compared to the other two domains. It should be pointed out that the information curve, as suggested by Pasquali (2007), shares an interface with both test parameters - validity and precision.

Concerning the factorial loadings obtained for the TCFe items, the high values indicate low residual variance (error), while high correlation between latent factors and items have been observed. According to Pasquali, such parameters indicate high determination coefficient values, thus granting validity to the item and indicating whether it is a "good behavioural representation of a latent trait" (p. 141).

With regard to the difficulty level (here, assessed by the thresholds - Table 2), in a general manner, the items in all three tasks are of medium difficulty (fluctuating between +1 and -1 ), and the assumption that the phonemic subtraction task with the CVC structure would be easier than with the CCV structure has not been confirmed. In other words, for the participant to deliver a correct answer during the tasks, they would need a medium amount of latent traits.

This is the premier study to provide evidence on factorial structure validity and precision of information for phonemic awareness tasks, which can be considered an advance in relation to the "actual tower of Babel" (Scliar-Cabral, 2002, p. 149) in which the elaboration of several assessment instruments for these skills are found (Godoy et al., 2014).

The analysed tasks have indicated the amplitude of latent factors to which they provide adequate information to measure phonemic-level phonological skills; more specifically, a greater precision in information can be observed among children with medium-level skills, since, as observed, the peak of the total information curve is centred around children with medium latent traits (around zero). Such distribution is expected, since, in a general manner, a skill test with a high precision of information throughout the entire latent trait spectrum cannot be obtained.

For future research that involves other properties of this model, it will be necessary and imperative to investigate, for instance, the invariance of the model among different population groups: one could ask if the proposed model remains stable with the children's schooling. Besides the invariance, convergent and divergent validity measures should add more information regarding this instrument's validation process.

\section{References}

American Educational Research Association, American Psychological Association, \& National Council on Measurement in Education. (2014). The standards for educational and psychological testing. Washington, DC: AERA.

Bentler, P. M. (1990). Comparative fit indexes in structural models. Psychological Bulletin, 107(2), 238-246. doi:10.1037/0033-2909.107.2.238

Bradley, L., \& Bryant, P. E. (1983). Categorizing sounds and learning to read: A causal connection. Nature, 301(5899), 419-421. doi:10.1038/301419a0

Capovilla, A. G. S., \& Capovilla, F. C. (1998). Prova de consciência fonológica: Desenvolvimento de dez habilidades da pré-escola à segunda série [Phonological awareness task: Development of ten skills from preschool to the second grade]. Temas Sobre Desenvolvimento, 7(37), 14-20.

Capovilla, A. G. S., \& Capovilla, F. C. (2000). Problemas de leitura e escrita: Como identificar, prevenir e remediar numa abordagem fônica [Reading and writing problems: How to identify, prevent, and intervene under a phonic approach]. São Paulo, SP: Memnon.

Caravolas, M. (2004). Spelling development in alphabetic writing systems: A cross-linguistic perspective. European Psychologist, 9(1), 3-14. doi:10.1027/1016-9040.9.1.3

Caravolas, M., Lervag, A., Defior, S., Málková, G. S., \& Hulme, C. (2013). Different patterns, but equivalent predictors, of growth in reading in consistent and inconsistent orthographies. Psychological Science, 24(8), 1398-1407. doi:10.1177/0956797612473122

Caravolas, M., Lervag, A., Mousikou, P., Efrim, C., Litavsky, M., Onochie-Quintanilla, E., . . . Hulme, C. (2012). Common patterns of prediction of literacy development in different alphabetic orthographies. Psychological Science, 23(6), 678-686. doi:10.1177/0956797611434536

Carson, K. L., Gillon, G. T., \& Boustead, T. M. (2013). Classroom phonological awareness instruction and literacy outcomes in the first year of school. Language, Speech, and Hearing Services in Schools, 44(2), 147-160. doi:10.1044/0161-1461(2012/11-0061) 
Castles, A., \& Coltheart, M. (2004). Is there a causal link from phonological awareness to success in learning to read? Cognition, 91(1), 77-111. doi:10.1016/S00100277(03)00164-1

Cossu, G., Shankweiler, D., Liberman, I.Y., Katz, L., \& Tola, G. (1988). Awareness of phonological segments and reading ability in Italian children. Applied Psycholinguistics, 9(1), 1-16. doi:10.1017/s0142716400000424

Defior, S., \& Serrano, F. (2011a). La conciencia fonémica, aliada de la adquisición del lenguaje escrito [Phonemic awareness and literacy acquisition]. Revista de Logopedia, Foniatría y Audiología, 31(1), 2-13. doi:10.1016/S02144603(11)70165-6

Defior, S., \& Serrano, F. (2011b). Procesos fonológicos explícitos e implícitos, lectura y dislexia [Explicit and implicit phonological processes, reading and dyslexia]. Revista Neuropsicología, Neuropsiquiatria y Neurociencias, 11(1), 79-94.

Defior, S., Serrano, F., \& Marín-Cano, M. J. (2008). El poder predictivo de las habilidades de conciencia fonológica en la lectura y escritura en castellano [The predictive powers of phonological skills in Castilian reading and writing]. In E. Diez-Itza (Ed.), Estudios de desarrollo del lenguaje $y$ educación [Language and education development studies] (pp. 339-348). Oviedo, Spain: Servicio de Publicaciones de la Universidad de Oviedo.

Dias, N. M., Duarte, C. P., Macedo, E. C., \& Seabra, A. G. (2012). Evidências de validade e fidedignidade da Prova de Consciência Fonológica por produção oral [Evidences of validity and reliability for Phonological Awareness Tests by oral production]. In A. G. Seabra \& N. M. Dias (Eds.) Avaliação neuropsicológica cognitiva: Linguagem oral [Cognitive neuropsychological assessment: Oral language] (Vol. 2, pp. 100-109). São Paulo, SP: Memnon.

Duncan, L. G., Castro, S. L., Defior, S., Seymour, P. H. K., Baillie, S., Leybaert, J., . . Serrano, F. (2013). Phonological development in relation to native language and literacy: Variations on a theme in six alphabetic orthographies. Cognition, 127(3), 398-419. doi:10.1016/j. cognition.2013.02.009

Ehri, L. C., Nunes, S. R., Willows, D. M., Schuster, B. V., Yaghoub-Zadeh, Z., \& Shanahan, T. (2001). Phonemic awareness instruction helps children learn to read: Evidence from the National Reading Panel's metaanalysis. Reading Research Quarterly, 36(3), 250-287. doi:10.1598/rrq.36.3.2

Godoy, D. M. A. (2001). Testes de consciência fonológica $e$ suas relações com a aprendizagem da leitura no português [Phonological awareness tests and their relation to learning reading in Portuguese] (Master's thesis, Universidade Federal de Santa Catarina, Florianópolis, Brazil). Retrieved from https://repositorio. ufsc.br/handle/123456789/82127

Godoy, D. M. A. (2005). Aprendizagem inicial da leitura e da escrita no português do Brasil: Influência da consciência fonológica e do método de alfabetização [Initial learning of reading and spelling in Brazilian Portuguese: Influence from phonological awareness and acquisition of literacy method] (Doctoral dissertation, Universidade Federal de Santa Catarina, Florianópolis, Brazil). Retrieved from https://repositorio.ufsc.br/handle/123456789/103092

Godoy, D. M. A., Defior, S., \& Pinheiro, A. M. V. (2007). Impacto do método de alfabetização sobre o desenvolvimento da consciência fonética, da leitura e da escrita no português do Brasil [The impact of the literacy method on the development of Brazilian Portuguese phonetic awareness, reading, and writing]. Educação: Temas e Problemas, 2(4), 81-99.

Godoy, D. M. A., Fortunato, N., \& Paiano, A. (2014). Panorama da última década de pesquisas com testes de consciência fonológica [Overview of the last decade of research with tests of phonological awareness]. Temas em Psicologia, 22(2), 313-328. doi:10.9788/TP2014.2-04

Godoy, D. M. A., \& Pinheiro, A. M. V. (2013). O que sabemos sobre a contribuição da consciência fonêmica para a aprendizagem inicial da leitura e da escrita [What we know about the contribution of phonemic awareness to early learning, reading, and writing]. In A. Roazzi, J. Salles, \& F. R. R. Justi (Eds.), A aprendizagem da leitura e da escrita: Contribuições de pesquisa [Learning to read and write: Research contributions] (pp. 9-30). São Paulo, SP: Vetor.

Gombert, J. E. (2003). Implicit and explicit learning to read: Implication as for subtypes of dyslexia. Current Psychology Letters: Behaviour, Brain \& Cognition, 10(1). Retrieved from http://cpl.revues.org/202

Green, S. B., Lissitz, R. W., \& Mulaik, S. A. (1977). Limitations of coefficient alpha as an index of test unidimensionality. Educational and Psychological Measurement, 37(4), 827-838. doi:10.1177/001316447703700403

Hu, L.-T., \& Bentler, P. M. (1998). Fit indices in covariance structure modeling: Sensitivity to underparameterized model misspecification. Psychological Methods, 3(4), 424-453. doi:10.1037/1082-989X.3.4.424

Hulme, C., \& Snowling, M. J. (2014). The interface between spoken and written language: Developmental disorders. Philosophical Transactions of the Royal Society of London. Series B, Biological Sciences, 369(1634), 20120395. doi:10.1098/rstb.2012.0395

Jöreskog, K. G. (1969). A general approach to confirmatory maximum likelihood factor analysis. Psychometrika, 34(2, Pt. 1), 183-202. doi:10.1007/BF02289343

Melby-Lervag, M., Lyster, S.-A. H., \& Hulme, C. (2012). Phonological skills and their role in learning to read: A meta-analytic review. Psychological Bulletin, 138(2), 322-352. doi:10.1037/a0026744

Moll, K., Ramus, F., Bartling, J., Bruder, J., Kunze, S., Neuhoff, N., ... Landerl, K. (2014). Cognitive mechanisms underlying reading and spelling development in five European orthographies. Learning and Instruction, 29, 65-77. doi:10.1016/j.learninstruc.2013.09.003 
Moojen, S., Lamprecht, R., Santos, R. M., Freitas, G. M., Brodacz, R., Siqueira, M., . . . Guarda, E. (2003). CONFIAS: Consciência fonológica: Instrumento de avaliação sequencial [CONFIAS: Phonological awareness: Tool for sequential assessment]. São Paulo, SP: Casa do Psicólogo.

Mousty, P., Leybaert, J., Alegria, J., Content, A., \& Morais, J. (1994). Belec: Une batterie d'évaluation du langage écrit et de ces troubles [Belec: A battery for reading and writing assessment and theirs difficulties]. In J. Grégoire \& B. Piérart (Eds.), Evaluer les troubles de la lecture [Assessing reading disorders] (pp. 127-145). Bruxelles, France: De Boeck-Wesmael.

Pasquali, L. (2007). TRI - Teoria de Resposta ao Item: Teoria, procedimentos e aplicações [Item Response Theory: Theory, procedures and applications]. Brasília, DF: LabPAM/UnB.

Raykov, T. (1997). Scale reliability, Cronbach's coefficient alpha, and violations of essential tau-equivalence with fixed congeneric components. Multivariate Behavioral Research, 32(4), 329-353. doi:10.1207/ s15327906mbr3204_2

Raykov, T. (2001). Bias of coefficient alpha for fixed congeneric measures with correlated errors. Applied Psychological Measurement, 25(1), 69-76. doi:10.1177/01466216010251005

Raykov, T., \& Marcoulides, G. A. (2011). Introduction to psychometric theory. New York, NY: Routledge.

Reise, S. P., Bonifay, W. E., \& Haviland, M. G. (2013). Scoring and modeling psychological measures in the presence of multidimensionality. Journal Personality Assessment, 95(2), 129-140. doi:10.1080/00223891.2012.725437

Reise, S. P., Moore, T. M., \& Haviland, M. G. (2010). Bifactor models and rotations: Exploring the extent to which multidimensional data yield univocal scale scores. Journal Personality Assessment, 92(6), 544-559. doi:10.1 080/00223891.2010.496477

Rothou, K. M., Padeliadu, S., \& Sideridis, G. D. (2013). Predicting early reading in Greek: The contribution of phonological awareness and non-phonological language skills. Procedia - Social and Behavioral Sciences, 93, 1504-1509. doi:10.1016/j.sbspro.2013.10.072

Scliar-Cabral, L. (2002). Capacidades metafonológicas e testes de avaliação: Implicações sobre o ensino do português [Metaphonological skills and evaluation tests: Impacts on Portuguese Teaching]. Perspectiva, 20(1), 139-156.

Tucker, L. R., \& Lewis, C. (1973). A reliability coefficient for maximum likelihood factor analysis. Psychometrika, 38(1), 1-10. doi:10.1007/BF02291170

Urbina, S. (2014). Essentials of psychological testing (2nd ed.). Hoboken, NJ: John Wiley \& Sons.

Wimmer, H., Landerl, K., Linortner, R., \& Hummer, P. (1991). The relationship of phonemic awareness to reading acquisition: More consequence than precondition but still important. Cognition, 40(3), 219-249. doi:10.1016/00100277(91)90026-Z
Dalva Maria Alves Godoy is Full Professor of the Universidade do Estado de Santa Catarina.

Hugo Cogo-Moreira is a postdoctoral researcher at the Universidade Federal de São Paulo.

Received: Nov. 26, 2014

1st Revision: Mar. 9, 2015

2nd Revision: Apr. 16, 2015

Approved: Apr. 26, 2015
How to cite this article:

Godoy, D. M. A., \& Cogo-Moreira, H. (2015). Evidences of factorial structure and precision of phonemic awareness tasks (TCFe). Paidéia (Ribeirão Preto), 25(62), 363-372. doi:10.1590/1982-43272562201510 